\title{
Implementasi Decision Support System Untuk Analisis Kelayakan Pendirian Minimarket Dengan Metode Fuzzy Analytical Hierarchy Process
}

\author{
WAHYU WIDODO ${ }^{1}$, HAIBAN ZAINUR ${ }^{2}$ \\ 1,2 Jurusan Teknik Informatika, STMIK El Rahma Yogyakarta \\ wahyu@stmikelrahma.ac.id
}

\begin{abstract}
ABSTRAK
Penentuan lokasi untuk mendirikan gerai baru minimarket masih dilakukan secara manual dan sering terjadi lokasi yang ditentukan tidak tepat sasaran karena tanpa mempertimbangkan faktor-faktor resiko yang akan terjadi. Maka perlu dibangun suatu Sistem Pendukung Keputusan Untuk Menentukan Lokasi Pendirian Gerai Baru pada Minimarket modern dengan memanfaatkan model Fuzzy Analytical Hierarchy Process (FAHP). Model ini melakukan penilaian kelayakan lokasi dengan 9 kriteria, yaitu jarak dengan pasar tradisional, dampak sosial lingkungan, rencana operasi, lokasi, akses jalan, jarak hunian, trafik, fasilitas pendukung, dan luas bangunan. Kemudian dilakukan pembobotan nilai kriteria yang menghasilkan pemeringkatan alternatif yang objektif. Hasil dari 8 kali pengujian dengan jumlah kriteria dan lokasi yang berbeda, perhitungan sensitifitas menujukan nilai sebesar 72.72 \%, maka dapat disimpulkan bahwa sistem pendukung keputusan ini sudah dapat berfungsi dengan baik untuk melakukan pemilihan lokasi pendirian gerai baru.
\end{abstract}

Kata kunci: sistem pendukung keputusan, Model FAHP, lokasi minimarket

\begin{abstract}
Abstract Determination of location to establish new outlets minimarket still done manually and often happened location that determined not right target because without considering risk factors that will happen. It is necessary to build a Decision Support System to Determine the Locations of New Store Locations in modern Minimarkets by utilizing Fuzzy Analytical Hierarchy Process (FAHP) model. This model conducts a site feasibility assessment with 9 criteria, ie distance to traditional market, environmental social impact, operating plan, location, access road, occupancy distance, traffic, supporting facilities, and building area. Then weighted the value of criteria that result in an objective alternative ranking. The result of 8 test with different criteria and location, the sensitivity calculation is $72.72 \%$, it can be concluded that the decision support system has been able to function well to choose the location of the new outlet.
\end{abstract}

Keywords: decision support system, FAHP model, determine the location minimarkets 


\section{PENDAHULUAN}

Didalam menghadapi persaingan bisnis retail yang semakin ketat, selain meningkatkan pelayanan dan fasilitas-fasilitas tambahan kepada pelanggan, juga mempunyai target untuk mendirikan gerai baru di setiap wilayah di seluruh wilayah Indonesia. Menghadapi target untuk mendirikan gerai baru, upaya melakukan observasi dan menganalisa beberapa alternatif tempat yang ada perlu dilakukan, apakah tempat yang ada memenuhi kriteria baik dari segi Peraturan Pemerintah Daerah, tentang aturan pendirian pasar modern, yang salah satunya mengatur tentang pendirian pasar modern, juga harus memperhatikan kriteria yang sudah ditetapkan bisnis retail tertentu (Puspitasari \& Subowo, 2014). Dari hasil analisa tersebut akan didapatkan hasil lokasi mana yang layak untuk didirikan gerai baru. Penentuan lokasi untuk mendirikan gerai baru, selama ini dikerjakan sepenuhnya oleh divisi pengembangan. Penentuan seperti ini sering berakibat pada lokasi yang ditentukan tidak tepat atau tidak sesuai (Saraswati, 2008). Hal tersebut terjadi karena penentuan lokasi masih dilakukan secara manual, kemudian data-data ditulis dalam lembar kerja tanpa mempertimbangkan faktor-faktor resiko yang akan terjadi dan terlihat adanya unsur subjektif, misalnya kedekatan pengusul dengan pihak manajemen menjadi pertimbangan tersendiri bagi pengambil kepustusan.

Penggunaan komputer telah berkembang dari sekedar pengolahan data dan penyaji informasi bagi manajemen, menjadi mampu untuk menyediakan solusi sebagai pendukung pengambilan keputusan yang dilakukan oleh manajemen (Faisol, Muslim, \& Suyono, 2014). Sistem Pendukung Pengambilan Keputusan (SPK) adalah suatu sistem komputer interaktif yang dapat memberikan alternatif solusi bagi pengambil keputusan, sehingga pengambilan keputusan dapat dilakukan dengan lebih cepat dan cermat. Dalam mempercepat dalam proses pengambilan keputusan serta menghindari subyektifitas keputusan yang dihasilkan diperlukan suatu sistem pendukung keputusan yang bertujuan untuk membantu pekerjaan manajemen, khususnya kepala divisi pengembangan sebagai pengambil keputusan dalam memutuskan lokasi mana yang sesuai untuk didirikan gerai baru melalui proses seleksi dengan menggunakan model Fuzzy Analytical Hierarchy Process (FAHP). Sistem akan membantu manajemen dalam membandingkan nilai kriteria,menerapkannya dalam matrik perbandingan berpasangan sehingga diperoleh bobot masing-masing kriteria baik kriteria lokal maupun global (Septilia Arfida, 2012).

Alasan memilih F-AHP karena proses yang membantu para pengambil keputusan untuk memperoleh solusi terbaik dengan mendekomposisi permasalahan kompleks ke dalam bentuk yang lebih sederhana untuk kemudian melakukan sintesis terhadap berbagai faktor yang terlibat dalam permasalahan pengambilan keputusan. F-AHP mempertimbangkan aspek kualitatif dan kuantitatif dari suatu keputusan dan mengurangi kompleksitas suatu keputusan dengan membuat perbandingan satu-satu dari berbagai kriteria yang dipilih untuk kemudian mengolah dan memperoleh hasilnya (Faisol et al., 2014). Alasan lainnya menggunakan FAHP adalah:

1) Metode F-AHP juga mampu menghasilkan hasil yang lebih konsisten dibandingkan dengan metode-metode lainnya;

2) Kesatuan (Unity), FAHP membuat permasalahan yang luas dan tidak terstruktur menjadi suatu model yang fleksibel dan mudah dipahami;

3) Pairwaise comparison F-AHP menggunakan data yang ada bersifat kualitatif berdasarkan pada persepsi, pengalaman, intuisi sehigga dirasakan dan diamati, namun kelengkapan data numerik tidak menunjang untuk memodelkan secara kuantitatif; 
4) F-AHP merupakan model yang komperehensif, pembuat keputusan menetukan pilihan atas pasangan perbandingan yang sederhana, membengun semua prioritas untuk urutan alternative;

5) F-AHP memiliki perhatian-perhatian khusus tentang penyimpangan dari konsistensi, pengukuran dan pada ketergantungan di dalam dan di antara kelompok elemen strukturnya. Berdasarkan latar belakang tersebut, penelitian ini dilakukan untuk membangun suatu Sistem Pendukung Keputusan Untuk Menentukan Lokasi Pendirian Gerai Baru pada Minimarket dengan memanfaatkan model Fuzzy Analytical Hierarchy Process (F-AHP).

\section{TINJAUAN PUSTAKA}

SPK digunakan untuk membantu pengambilan keputusan dalam situasi yang semitersruktur dan situasi yang tidak terstruktur, dimana tak seorang pun tahu secara pasti bagaimana keputusan seharusnya dibuat. SPK dibangun untuk mendukung solusi atas suatu masalah atau untuk mengevaluasi suatu peluang. SPK ditujukan untuk mendukung manajemen dalam melakukan pekerjaan yang bersifat analitis dalam situasi yang kurang terstruktur dan dengan kriteria yang kurang jelas (Sonalitha, Sarosa, \& Naba, 2015). Akan tetapi tidak dimaksudkan untuk mengotomatisasikan pengambilan keputusan, melainkan untuk memberikan perangkat interaktif yang memungkinkan pengambil keputusan untuk melakukan berbagai analisis menggunakan model-model yang tersedia. Tujuan utama SPK adalah:

1) membantu manajer dalam pengambilan keputusan atas masalah semi-terstruktur;

2) memberikan dukungan atas pertimbangan manajer;

3) meningkatkan efektifitas keputusan yang diambil;

4) kecepatan komputasi;

5) peningkatan produktifitas;

6) dukungan kualitas;

7) berdaya saing; dan

8) mengatasi keterbatasan kognitif Sistem pendukung keputusan terdiri atas 4 komponen yaitu, subsistem manajemen data, subsistem manajemen model, subsistem antarmuka pengguna dan subsistem manajemen berbasis-pengetahuan.

\subsection{Subsistem Manajemen Data}

Pada dasarnya subsistem manajemen data terdiri dari beberapa komponen utama, yaitu:

a. Basis data sistem pendukung keputusan, yaitu kumpulan data yang saling berhubungan, dan diorganisasikan untuk memenuhi kebutuhan dan struktur dari sebuah organisasi yang dapat digunakan oleh lebih dari satu orang untuk beberapa aplikasi.

b. Fasilitas query, diperlukan untuk mengakses, memanipulasi, dan query data.

c. Direktori data, yaitu katalog dari semua data di dalam basis data.

\subsection{Subsistem Manajemen Model}

Sebuah basis model berisi rutin khusus dan model-model yang menyediakan kemampuan analisis pada suatu sistem pendukung keputusan. Kemampuan menciptakan, menjalankan, merubah, menggabungkan, dan memeriksa modelmodel adalah kunci kemampuan dari sebuah sistem pendukung keputusan yang membedakannya dengan sistem informasi berbasis komputer lainnya.

\subsection{Subsistem Manajemen Pengetahuan}

Beberapa aplikasi sistem pendukung keputusan yang permasalahannya tidak terlalu kompleks, tidak memerlukan subsistem manajemen pengetahuan oleh karena itu subsistem 
ini bersifat optional. Akan tetapi, banyak permasalahan semi terstruktur dan tidak terstruktur yang sangat kompleks sehingga untuk solusinya membutuhkan keahlian sebagai tambahan kemampuan terhadap sistem pendukung keputusan reguler. Keahlian dapat disediakan oleh sebuah sistem pakar atau sistem inteligen lainnya. Oleh karena itu, banyak sistem pendukung keputusan yang telah maju dilengkapi dengan sebuah komponen yang disebut manajemen pengetahuan.

\subsection{Subsistem Antarmuka Pengguna}

Antarmuka pengguna meliputi semua aspek komunikasi antara pengguna dengan sistem pendukung manajemen. Subsistem antar muka pengguna dikelola oleh perangkat lunak yang disebut sistem manajemen antarmuka pengguna.

\subsection{Fuzzy AHP}

Model AHP pertama yang dikembangkan oleh Thomas L. Saaty (1990) merupakan AHP dengan pembobotan additive, disebut additive karena operasi aritmatika untuk mendapatkan bobot totalnya adalah penjumlahan. Selanjutnya beberapa model F-AHP dengan pembobotan additive telah dikembangkan oleh beberapa peneliti(Fuadi \& Juniani, 2015). Akan tetapi dari beberapa model yang ada ini untuk suatu kasus tertentu terdapat beberapa kekurangan, sehingga dikembangkanlah model Fuzzy AHP dengan pembobotan non-additive (Wahyuni \& Sri, 2012). Pembahasan dalam makalah ini mengacu pada model AHP nonadditive, dimana secara umum prosedur perhitungannya terdiri dari empat langkah, yaitu (1) penilaian alternatif terhadap setiap kriteria, (2) pembobotan kriteria, (3) perhitungan nilai akhir, dan (4) ranking dan keputusan akhir.

Pada langkah (1) yaitu penilaian alternatif, pengambil keputusan diminta memberikan suatu rangkaian penilaian terhadap alternatif $\mathrm{x}$ yang ada dalam bentuk bilangan fuzzy triangular (TFN), yang disusun berdasarkan variabel linguistik. Selanjutnya, nilai fuzzy didefinisikan bagi setiap alternatif pada setiap kriteria. Dalam TFN diberikan tiga kondisi untuk nilai fungsi keanggotaan, yaitu pesimis, paling disukai dan optimis, seperti pada "Gambar 1. Fungsi Keanggotaan Triangular".

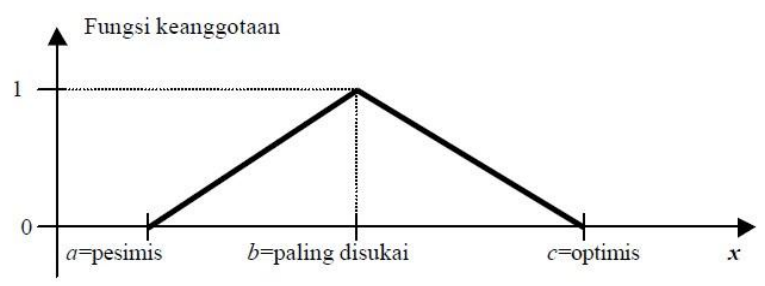

\section{Gambar 1. Fungsi Keanggotaan Triangular}

Dalam langkah (2), yaitu pembobotan kriteria, Zeleny (1983) membaginya menjadi dua tipe yaitu: (1) bobot prior wi, yang sifatnya relatif stabil, menggambarkan keadaan psikologis dan sosial dari pengambil keputusan, (2) bobot informasi li , sifatnya tidak stabil.

Bobot prior, pada dasarnya merupakan modifikasi pembobotan AHP yang dikembangkan oleh Saaty. Dimana langkah-langkah perhitungannya adalah sebagai berikut:

a. Menentukan perbandingan berpasangan seperti pada persamaan (1).

$$
a_{i, j}=\frac{w_{i}}{w_{j}}, i, j=1,2, \ldots, n
$$


dimana n menyatakan jumlah kriteria yang dibandingkan, wi bobot untuk kriteria ke-i, dan $a_{i, j}$ adalah perbandingan bobot kriteria ke-i dan j. Jika indeks konsistensi lebih besar dari satu, maka perbandingan berpasangan harus diulang.

b. Menormalkan setiap kolom dengan cara membagi setiap nilai pada kolom kei dan baris ke-j dengan nilai terbesar pada kolom ke-i seperti pada persamaan (2).

$$
\hat{a} i j=\frac{a_{i j}}{m a_{x a_{i j}}}, \forall i, j
$$

c. Menjumlahkan nilai pada setiap kolom ke-i, yaitu seperti pada persamaan (3).

$$
\hat{a}_{i}=\sum_{j} \hat{a}_{i j}, \forall i
$$

d. Akhirnya bobot prior bagi setiap kriteria ke-i, didapat dengan membagi setiap nilai $\mathrm{i}$ $a^{\wedge}$ dengan jumlah kriteria yang dibandingkan (n), yaitu seperti pada persamaan (4).

$$
\widehat{w}_{i}=\frac{\hat{a}_{i}}{n}, \forall i
$$

Bobot informasional, yaitu mengandung nilai-nilai yang diberikan pada setiap alternatif, dalam hal ini akan digunakan metode entropy yang dikembangkan oleh Zeleny (1983). Langkah-langkah perhitungannya adalah sebagai berikut: Defuzzyfikasi skor fuzzy pada setiap kriteria ke-I alternatif ke-j menggunakan titik berat atau centroid dengan menggunakan persamaan (5a).

$$
d_{i j}(x)=\frac{\int_{a}^{c} c(x) x d x}{\int_{a}^{c} c(x) d x}
$$

dimana $C(x)$ merupakan fungsi keanggotaan yang kontinu dari $x$ pada himpunan fuzzy Sedangkan, untuk fungsi keanggotaan yang diskrit maka titik beratnya dirumuskan seperti pada persamaan (5b).

$$
d_{i j}(x)=\frac{\sum_{k=1}^{n} c\left(x_{k}\right) x_{k}}{\sum_{k=1}^{n} c\left(x_{k}\right)}
$$

e. Membentuk matriks iXj dan menormalkan dij, dengan cara membagi nilai pada setiap kolom ke-i dengan nilai terbesar pada kolom tersebut seperti pada persamaan(6).

$$
\hat{d}_{i j}=\frac{d_{i j}}{\max d_{i j}}, \forall i, j
$$

f. Menjumlahkan nilai yang telah dinormalkan pada setiap kriteria menjadi Di untuk semua I, seperti pada persamaan(7).

$$
e\left(d_{i}\right)=-k \sum_{j=1}^{n} \frac{\hat{d}_{i j}}{D i} \ln \left(\frac{d_{i j}}{D_{i}}\right), i=1,2, \ldots, n
$$

g. Menghitung bobot informasional untuk setiap kriteria ke-i, seperti pada persamaan(8).

$$
\hat{\lambda}_{i}=\frac{1}{n-\sum_{i=1}^{n} e\left(d_{i}\right)}\left[1-e\left(d_{i}\right)\right]
$$

h. Akhirnya, total bobot kriteria ke-I dapat dirumuskan sebagai mana pada persamaan(9)

$$
\hat{\lambda}_{i}=\widehat{w}_{i}^{T} x \hat{\lambda}_{i}, i=1,2, \ldots, n
$$


Jika nilai total bobot li yang terbesar tidak mendekati satu, maka harus dinormalkan, seperti pada persamaan (10).

$$
\hat{\lambda}_{i}=\frac{\hat{\lambda}_{i}}{\max _{i}},=1,2, \ldots, n
$$

Langkah ke-(3), Perhitungan nilai akhir, langkah-langkah perhitungannya meliputi:

a. Menetapkan nilai possibility dari setiap alternatif, yaitu i i $\sim r=1$, selanjutnya nilainilai ini disusun dari yang terkecil sampai dengan terbesar seperti pada persamaan(11).

$$
w=\left\{r_{1}^{T}, r_{2}^{T}, \ldots, r_{n}^{T}\right\}
$$

b. Menentukan dasar ketetapan dari setiap himpunan menggunakan persamaan(12)

$$
r_{i}^{T}-r_{2 i-1}^{T}=m\left(A_{i}\right)
$$

c. Peringkat dari bilangan fuzzy didapatkan dari evaluasi setiap alternatif didasarkan pada kriteria yang berhubungan dengan nilai batas atas yang diharapkan $\mathrm{E}^{*}$ dan nilai batas bawah yang diharapkan $\mathrm{E}^{*}$ seperti pada persamaan (13) :

$$
\begin{aligned}
& E^{*}(f)=\sum_{i=1}^{n}\left(r_{i}-r_{i-1}\right)_{y \in A^{*}}^{\max } f(y) \\
& E_{*}(f)=\sum_{i=1}^{n}\left(r_{i}-r_{i-1}\right)_{y \in A_{*}}^{\min x} f(y)
\end{aligned}
$$

Langkah (4), ranking dan keputusan akhir. Untuk mendapatkan nilai total pada level tertinggi (keputusan akhir), maka nilai-nilai yang didapat dari setiap sub hierarki harus diagregat. Langkah-langkahnya adalah:

a. Misalkan 0, 1, .., $\mathrm{n}$ adalah level dari hierarki, dengan $\mathrm{n}$ sekurang-kurangnya 2, dalam hal ini hierarki 0 adalah tujuan dan hierarki $n$ adalah alternatif. Definisikan nilai dari setiap alternatif dibawah kriteria $\mathrm{j}$ pada hierarki idalah $\mathrm{fi}, \mathrm{j}(\mathrm{x})$, maka nilai alternatif dapat dirumuskan seperti persamaan(14).

$$
f_{i, j}(x)=\sum_{j} w_{i-1, j} f_{i-1, j}(x)
$$

dimana $\mathrm{j}$ adalah indeks yang relevan terhadap banyaknya alternatif. Langkah ini dilakukan dari $\mathrm{i}=\mathrm{n}-2$ sampai $\mathrm{i}=0$. Saat $\mathrm{i}=0$ tidak ada lagi kriteria ke-j yang sesuai karena tidak ada kriteria pada hierarki 0 , maka pada saat $\mathrm{i}=0$ akan didadat nilai akhir untuk setiap kriteria, dinyatakan dengan $f(x)$, dimana nilai akhir dari $f(x)$ ini berupa bilangan fuzzy.

b. Untuk menentukan peringkat dari nilai akhir, pertama harus ditentukan dulu pusat grafitasi $F$ untuk setiap nilai akhir dari suatu alternatif, yang dirumuskan seperti pada persamaan(15).

$$
\begin{aligned}
& \Delta u=\left((\phi-b)+\frac{1}{2(b-a)}\right) / 10 \\
& \Delta u=\left((b-\phi)+\frac{1}{2(c-b)}\right) / 10 \\
& \phi u M=\phi M-\Delta u M,
\end{aligned}
$$

diasumsikan $M$ adalah bilangan fuzzy dengan $F$ yang lebih besar daripada N. Jika FN>FuM maka $\mathrm{M}$ lebih besar dari $\mathrm{N}$ (alternatif $\mathrm{M}$ lebih baik dari alternatif $\mathrm{N}$ ). 


\subsection{Perencanaan Sistem}

Sistem Pendukung Keputusan Penentuan Lokasi Pendirian Gerai Baru ini merupakan sebuah sistem yang dapat berguna untuk membantu bagian pengembangan sebagai pengambil keputusan dalam menentukan lokasi pendirian gesai baru yang diajukan oleh beberapa kolega atau pengembangan dari perusahaan itu sediri. Sistem ini hanya digunakan oleh tim pengembangan sebagai alat bantu menentukan calon lokasi yang tepat untuk mendirikan gerai baru. Dengan memanfaatkan metode F-AHP sebagai model dalam Sistem Pendukung Keputusan ini, Tim pengembangan melakukan tugasnya sebagai pengambil keputusan dengan memberi nilai kesukaan relatif masing-masing kriteria yang disebut tabel perbandingan berpasangan kriteria dengan mengacu pada nilai yang telah ditentukan yaitu nilai dengan skala 1 sampai 9. Selanjutnya dapat ditentukan tabel bobot masing-masing criteria.

Dalam sistem ini, peneliti memberikan data diri dan data lokasi yang akan digunakan untuk membuka gerai baru. Dari data tersebut, maka sistem akan memprosesnya dan menampilkan nilai dari setiap lokasi yang ada dan kemudian memutuskan lokasi yang layak untuk dibangun sebuah gerai baru. Sistem akan memilih secara otomatis berdasarkan kriteria yang digunakan, yaitu lokasi yang layak untuk didirikan gerai baru tersebut. Setelah melakukan langkah-langkah dalam metode F-AHP yang digunakan sebagai dasar pemecahan masalah, langkah selanjutnya adalah rancang bangun sistem yang digunakan sebagai alternative pengambilan keputusan.Rancang bangun ini kemudian dibuat implementasinya dalam sebuah perangkat lunak yang diharapkan memudahkan pemakainya, baik dalam tingkat operatornya maupun tingkat pengambilan keputusannya.

\subsection{Analisis Kebutuhan Sistem}

Untuk dapat menghasilkan suatu informasi yang baik, maka diperlukan juga data-data yang baik, karena informasi pada dasarnya merupakan hasil dari pengolahan data yang diinput pada sistem. Berdasarkan penelitian yang dilakukan, di diperoleh data-data yang dibutuhkan dalam perancangan sistem pendukung keputusan penentuan lokasi pendirian gerai baru. Data yang diperoleh kemudian diolah dan menjadi data yang siap diimplementasikan dalam sistem. Selama ini analisis dan penentuan lokasi pendirian gerai baru masih dilakukan secara manual. Sistem pendukung keputusan yang dibuat yaitu jenis pendukung keputusan yang meberikan keputusan menunggu legitimasi dari pihak manajemen untuk dilaksanakan. Aplikasi ini dapat digunakan untuk berbagai tingkatan managerial dan mendukung proses pengambilan keputusan tersetruktur. Aplikasi ini menggunakan pendekatan top down yang merupakan ciri dari perancangan tersetruktur. Aplikasi melibatkan kemampuan untuk melihat data internal berupa calon lokasi dan data ekternal berupa data kriteria penilaian. Sehingga pembuat keputusan dapat mendiskusikan kriteria dan menggunakan alternatif yang beragam.

Dalam F-AHP suatu masalah kompleks dan tidak tersetruktur dipecahkan kedalam kelompokkelompoknya, kemudian kelompok-kelompok tersebut diatur menjadi suatu bentuk hirarki. Sistem pendukung keputusan hanya memberikan masukan untuk penyelesaian untuk dikerjakan tapi tidak membuat pilihan. Aplikasi ini mudah digunakan dan pengambilan keputusan mempunyai kontrol terhadap semua hingga membuat keputusan dengan mengesampingkan rekomendasi komputer saat proses berlangsung. Dari penelitian yang dilakukan diperoleh data-data yang dibutuhkan dalam perancangan sistem pendukung keputusan ini. Data-data yang perlu disediakan pada sebuah lokasi terdiri dari beberapa item sebagaimana disajikan pada "Tabel 1. Data Lokasi". Data yang diperoleh kemudian diolah 
dan menjadi data yang siap diimplementasikan dalam sistem. Data masukannya sistem meliputi data lokasi dan data kriteria.

Tabel 1. Data lokasi

\begin{tabular}{|l|l|l|}
\hline \multicolumn{1}{|c|}{ No } & \multicolumn{1}{|c|}{ Item Data } & \multicolumn{1}{c|}{ Keterangan } \\
\hline 1. & Inisial & Inisial lokasi pembangunan minimarket \\
\hline 2. & Kecamatan & Kecamatan dimana lokasi berada \\
\hline 3. & Pengusul & Nama pengusul /investor \\
\hline 4. & Alamat Rumah & Alamat rumah pengusul \\
\hline 5. & No KTP & Nomor KTP pengusul \\
\hline 6. & Pekerjaan & Pekerjaan pengusul \\
\hline 7. & Lokasi & lokasi pembangunan minimarket \\
\hline 8. & Latitude & Koordinat Latitude lokasi pembangunan minimarket \\
\hline 9. & Longitude & Koordinat Longitude lokasi pembangunan minimarket \\
\hline
\end{tabular}

Sedangkan beberapa kriteria yang digunakan untuk melakukan penilaian kelayakan sebuah lokasi ditentukan pada beberapa item sebagaimana disajikan pada "Tabel 2. Data Kriteria Penilaian".

Tabel 2. Data kriteria penilaian

\begin{tabular}{|l|l|l|}
\hline Kode & Inisial & \multicolumn{1}{c|}{ Kriteria } \\
\hline KR01 & JPT & Jarak dengan pasar tradisional \\
\hline KR02 & DSL & Dampak sosial lingkungan \\
\hline KR03 & ROP & Rencana operasi \\
\hline KR04 & LKS & Lokasi \\
\hline KR05 & AKJ & Akses jalan \\
\hline KR06 & HNN & Hunian (jarak 1-2 km) \\
\hline KR07 & TRF & Trafik (dihitung tiap 15 menit) \\
\hline KR08 & FSP & Fasilitas pendukung \\
\hline KR09 & LSB & Luas bangunan \\
\hline
\end{tabular}

Adapun urutan langkahnya sebagai berikut :

1) Melakukan proses penghitungan untuk sembilan kriteria yang telah ditentukan, untuk mendapatkan bobot prioritas.

2) Melakukan proses penghitungan nilai kelayakan lokasi berdasarkan pertimbangan Sembilan kriteria yang telah ditentukan. Prosesn ini diperlukan untuk mendapatkan bobot prioritas dari masing-masing lokasi berdasarkan sembilan kriteria penilaian.

3) Melakukan proses penghitungan untuk bobot prioritas total berdasarkan bobot kriteria dan bobot lokasi yang telah dihitung.

4) Kebutuhan keluaran (output) Keluaran berupa grafik, rengking dan laporan kelayakan lokasi berdasarkan perbandingan kriteria, atau secara global (perbandingan secara keseluruhan).

\subsection{Desain Sistem}

Desain sistem meliputi kegiatan perancangan dan konstruksi, baik desain yang berhubungan dengan alur sistem, pemrosesan sampai dengan rancangan antar muka (inteface) sistem yang akan bangun. Desain dalam membangun sistem pendukung keputusan penentuan lokasi pendirian gerai baru ini terdiri dari desain diagram alir data (DAD), desain basis data dan desain antar muka. Alur proses sistem dengan metode FAHP dapat dijelaskan pada "Gambar 2. Alur Proses Sistem". 


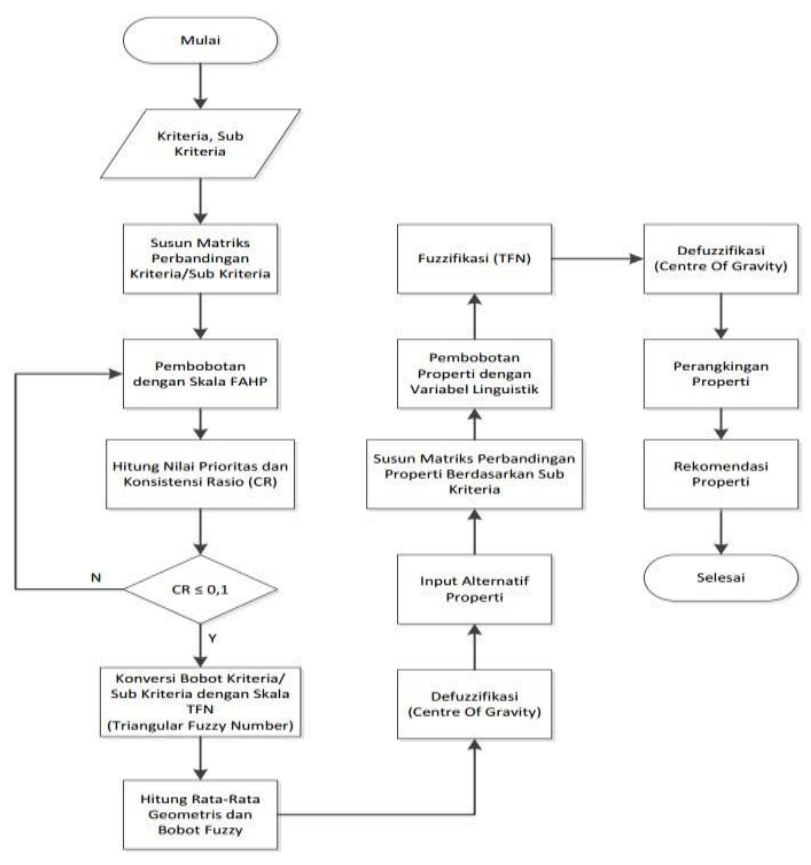

Gambar 2. Alur Proses Sistem

\section{IMPLEMENTASI SISTEM DAN HASIL}

Pertama-tama menyusun hirarki dimana diawali dengan tujuan, kriteria dan alternatifalternatif lokasi pada tingkat paling bawah. Terdapat alternative lokasi yang berada di Kabupaten Kulonprogo antarlain : Sentolo [SEN01],Wates [WAT02],Pengasih [PEN04],Nanggulan [NAN02],Temon [TEMON07],Kalibawang [KAL01],Samigaluh [SAM02], dan Panjatan [PAN01]. Selanjutnya menetapkan perbandingan berpasangan antara kriteriakriteria dalam bentuk matrik nilai diagonal matrik untuk perbandingan suatu elemen dengan elemen itu sendiri diisi dengan bilangan satu sedangkan isi nilai perbandingan antara satu sampai dengan sembilan kebalikannya, kemudian dijumlahkan perkolom data matrik tersebut seperti pada "Tabel 3. Matrik Perbandingan Kriteria".

Tabel 3. Matrik Perbandingan Kriteria

\begin{tabular}{|c|c|c|c|c|c|c|c|c|c|c|c|c|c|c|c|}
\hline & JPT & DSL & ROP & LKS & AKS & HNN & TRF & FSP & LSB & $\mathrm{JLN}$ & ARP & KPT & BSS & PMS & RIB \\
\hline JPT & 1 & 2 & 1 & 2 & 1 & 1 & 4 & 3 & 4 & 2 & 1 & 2 & 3 & 2 & 4 \\
\hline DSL & 0.50 & 1 & 1 & 3 & 4 & 5 & 5 & 5 & 4 & 1 & 3 & 4 & 3 & 3 & 6 \\
\hline ROP & 1.00 & 1.00 & 1 & 2 & 4 & 2 & 2 & 2 & 4 & 2 & 4 & 2 & 3 & 2 & 4 \\
\hline LKS & 0.50 & 0.33 & 0.50 & 1 & 3 & 3 & 3 & 3 & 4 & 1 & 5 & 2 & 3 & 3 & 2 \\
\hline AKS & 1.00 & 0.25 & 0.25 & 0.33 & 1 & 2 & 3 & 2 & 3 & 1 & 5 & 2 & 4 & 1 & 1 \\
\hline HNN & 1.00 & 0.20 & 0.50 & 0.33 & 0.50 & 1 & 2 & 1 & 2 & 4 & 5 & 4 & 1 & 5 & 2 \\
\hline TRF & 0.25 & 0.20 & 0.50 & 0.33 & 0.33 & 0.50 & 1 & 2 & 3 & 6 & 4 & 2 & 5 & 2 & 3 \\
\hline FSP & 0.33 & 0.20 & 0.50 & 0.33 & 0.50 & 1.00 & 0.50 & 1 & 2 & 4 & 1 & 4 & 2 & 4 & 2 \\
\hline LSB & 0.25 & 0.25 & 0.25 & 0.25 & 0.50 & 0.50 & 0.33 & 0.50 & 1 & 2 & 3 & 2 & 2 & 2 & 2 \\
\hline JLN & 0.50 & 1.00 & 0.50 & 1.00 & 1.00 & 0.25 & 0.17 & 0.25 & 0.50 & 1 & 2 & 1 & 4 & 4 & 1 \\
\hline ARP & 1.00 & 0.33 & 0.25 & 0.20 & 0.20 & 0.20 & 0.25 & 1.00 & 0.33 & 0.50 & 1 & 2 & 1 & 5 & 2 \\
\hline KPT & 0.50 & 0.25 & 0.50 & 0.50 & 0.50 & 0.25 & 0.50 & 0.25 & 0.50 & 1.00 & 0.50 & 1 & 4 & 4 & 1 \\
\hline BSS & 0.33 & 0.33 & 0.33 & 0.33 & 0.25 & 1.00 & 0.20 & 0.50 & 0.50 & 0.25 & 1.00 & 0.25 & 1 & 1 & 1 \\
\hline PMS & 0.50 & 0.33 & 0.50 & 0.33 & 1.00 & 0.20 & 0.50 & 0.25 & 0.50 & 0.25 & 0.20 & 0.25 & 1.00 & 1 & 4 \\
\hline RIB & 0.25 & 0.17 & 0.25 & 0.50 & 1.00 & 0.50 & 0.33 & 0.50 & 0.50 & 1.00 & 0.50 & 1.00 & 1.00 & 0.25 & 1 \\
\hline umlah & 8.92 & 7.85 & 7.83 & 12.45 & 18.78 & 18.40 & 22.78 & 22.25 & 29.83 & 27.00 & 36.20 & 29.50 & 38.00 & 39.25 & 36.00 \\
\hline
\end{tabular}

Setelah terbentuk matrik maka dilihat bobot prioritas untuk perbandingan kriteria. Dengan cara membagi isi matrik perbandingan dengan jumlah kolom yang bersesuaian, kemudian menjumlahkan perbaris dengan banyak kriteria yang diperbandingakan sehingga ditemukan bobot prioritas seperti yang terlihat pada "Tabel 4 Perhitungan Matrik Perbandingan Kriteria". 
Tabel 4. Perhitungan Matrik Perbandingan Kriteria

\begin{tabular}{|c|c|c|c|c|c|c|c|c|c|c|c|c|c|c|c|c|c|}
\hline & JPT & DSL & ROP & LKS & AKS & HNN & TRF & FSP & LSB & JLN & ARP & KPT & BSS & PMS & RIB & Jmlh Brs & Bobot \\
\hline JPT & 0.11 & 0.25 & 0.13 & 0.16 & 0.05 & 0.05 & 0.18 & 0.13 & 0.13 & 0.07 & 0.03 & 0.07 & 0.08 & 0.05 & 0.11 & 1.6178 & 0.1079 \\
\hline DSL & 0.06 & 0.13 & 0.13 & 0.24 & 0.21 & 0.27 & 0.22 & 0.22 & 0.13 & 0.04 & 0.08 & 0.14 & 0.08 & 0.08 & 0.17 & 2.1926 & 0.1462 \\
\hline ROP & 0.11 & 0.13 & 0.13 & 0.16 & 0.21 & 0.11 & 0.09 & 0.09 & 0.13 & 0.07 & 0.11 & 0.07 & 0.08 & 0.05 & 0.11 & 1.6546 & 0.1103 \\
\hline LKS & 0.06 & 0.04 & 0.06 & 0.08 & 0.16 & 0.16 & 0.13 & 0.13 & 0.13 & 0.04 & 0.14 & 0.07 & 0.08 & 0.08 & 0.06 & 1.4199 & 0.0947 \\
\hline AKS & 0.11 & 0.03 & 0.03 & 0.03 & 0.05 & 0.11 & 0.13 & 0.09 & 0.10 & 0.04 & 0.14 & 0.07 & 0.11 & 0.03 & 0.03 & 1.0882 & 0.0725 \\
\hline HNN & 0.11 & 0.03 & 0.06 & 0.03 & 0.03 & 0.05 & 0.09 & 0.04 & 0.07 & 0.15 & 0.14 & 0.14 & 0.03 & 0.13 & 0.06 & 1.1401 & 0.0760 \\
\hline TRF & 0.03 & 0.03 & 0.06 & 0.03 & 0.02 & 0.03 & 0.04 & 0.09 & 0.10 & 0.22 & 0.11 & 0.07 & 0.13 & 0.05 & 0.08 & 1.0898 & 0.0727 \\
\hline FSP & 0.04 & 0.03 & 0.06 & 0.03 & 0.03 & 0.05 & 0.02 & 0.04 & 0.07 & 0.15 & 0.03 & 0.14 & 0.05 & 0.10 & 0.06 & 0.8898 & 0.0593 \\
\hline LSB & 0.03 & 0.03 & 0.03 & 0.02 & 0.03 & 0.03 & 0.01 & 0.02 & 0.03 & 0.07 & 0.08 & 0.07 & 0.05 & 0.05 & 0.06 & 0.6202 & 0.0413 \\
\hline JLN & 0.06 & 0.13 & 0.06 & 0.08 & 0.05 & 0.01 & 0.01 & 0.01 & 0.02 & 0.04 & 0.06 & 0.03 & 0.11 & 0.10 & 0.03 & 0.7909 & 0.0527 \\
\hline ARP & 0.11 & 0.04 & 0.03 & 0.02 & 0.01 & 0.01 & 0.01 & 0.04 & 0.01 & 0.02 & 0.03 & 0.07 & 0.03 & 0.13 & 0.06 & 0.6144 & 0.0410 \\
\hline KPT & 0.06 & 0.03 & 0.06 & 0.04 & 0.03 & 0.01 & 0.02 & 0.01 & 0.02 & 0.04 & 0.01 & 0.03 & 0.11 & 0.10 & 0.03 & 0.6018 & 0.0401 \\
\hline BSS & 0.04 & 0.04 & 0.04 & 0.03 & 0.01 & 0.05 & 0.01 & 0.02 & 0.02 & 0.01 & 0.03 & 0.01 & 0.03 & 0.03 & 0.03 & 0.3898 & 0.0260 \\
\hline PMS & 0.06 & 0.04 & 0.06 & 0.03 & 0.05 & 0.01 & 0.02 & 0.01 & 0.02 & 0.01 & 0.01 & 0.01 & 0.03 & 0.03 & 0.11 & 0.4894 & 0.0326 \\
\hline RIB & 0.03 & 0.02 & 0.03 & 0.04 & 0.05 & 0.03 & 0.01 & 0.02 & 0.02 & 0.04 & 0.01 & 0.03 & 0.03 & 0.01 & 0.03 & 0.4008 & 0.0267 \\
\hline
\end{tabular}

Bobot konsistensi dihitung dengan cara membagi jumlah nilai baris dengan bobot kriteria sesuai dengan masing-masing kriteria.Dari hasil perhitungan bobot konsistensi dapat dihitung perbandingan konsistensi seperti pada "Tabel 5 Matrik Perhitungan Bobot Konsistensi".

Tabel 5. Matrik Perhitungan Bobot Konsistensi

\begin{tabular}{|c|c|c|c|c|c|c|c|c|c|c|c|c|c|c|c|c|c|}
\hline & JPT & DSL & ROP & LKS & AKS & HNN & TRF & FSP & LSB & JLN & ARP & KPT & BSS & PMS & RIB & Jmlh Brs & Bobot \\
\hline JPT & 0.11 & 0.29 & 0.11 & 0.19 & 0.07 & 0.08 & 0.29 & 0.18 & 0.17 & 0.11 & 0.04 & 0.08 & 0.08 & 0.07 & 0.11 & 1.9591 & 18.1642 \\
\hline DSL & 0.05 & 0.15 & 0.11 & 0.28 & 0.29 & 0.38 & 0.36 & 0.30 & 0.17 & 0.05 & 0.12 & 0.16 & 0.08 & 0.10 & 0.16 & 2.7621 & 18.8961 \\
\hline ROP & 0.11 & 0.15 & 0.11 & 0.19 & 0.29 & 0.15 & 0.15 & 0.12 & 0.17 & 0.11 & 0.16 & 0.08 & 0.08 & 0.07 & 0.11 & 2.0248 & 18.3559 \\
\hline LKS & 0.05 & 0.05 & 0.06 & 0.09 & 0.22 & 0.23 & 0.22 & 0.18 & 0.17 & 0.05 & 0.20 & 0.08 & 0.08 & 0.10 & 0.05 & 1.8265 & 19.2946 \\
\hline AKS & 0.11 & 0.04 & 0.03 & 0.03 & 0.07 & 0.15 & 0.22 & 0.12 & 0.12 & 0.05 & 0.20 & 0.08 & 0.10 & 0.03 & 0.03 & 1.3898 & 19.1565 \\
\hline HNN & 0.11 & 0.03 & 0.06 & 0.03 & 0.04 & 0.08 & 0.15 & 0.06 & 0.08 & 0.21 & 0.20 & 0.16 & 0.03 & 0.16 & 0.05 & 1.4421 & 18.9737 \\
\hline TRF & 0.03 & 0.03 & 0.06 & 0.03 & 0.02 & 0.04 & 0.07 & 0.12 & 0.12 & 0.32 & 0.16 & 0.08 & 0.13 & 0.07 & 0.08 & 1.3562 & 18.6672 \\
\hline FSP & 0.04 & 0.03 & 0.06 & 0.03 & 0.04 & 0.08 & 0.04 & 0.06 & 0.08 & 0.21 & 0.04 & 0.16 & 0.05 & 0.13 & 0.05 & 1.0908 & 18.3871 \\
\hline LSB & 0.03 & 0.04 & 0.03 & 0.02 & 0.04 & 0.04 & 0.02 & 0.03 & 0.04 & 0.11 & 0.12 & 0.08 & 0.05 & 0.07 & 0.05 & 0.7635 & 18.4658 \\
\hline JLN & 0.05 & 0.15 & 0.06 & 0.09 & 0.07 & 0.02 & 0.01 & 0.01 & 0.02 & 0.05 & 0.08 & 0.04 & 0.10 & 0.13 & 0.03 & 0.9250 & 17.5435 \\
\hline ARP & 0.11 & 0.05 & 0.03 & 0.02 & 0.01 & 0.02 & 0.02 & 0.06 & 0.01 & 0.03 & 0.04 & 0.08 & 0.03 & 0.16 & 0.05 & 0.7142 & 17.4358 \\
\hline KPT & 0.05 & 0.04 & 0.06 & 0.05 & 0.04 & 0.02 & 0.04 & 0.01 & 0.02 & 0.05 & 0.02 & 0.04 & 0.10 & 0.13 & 0.03 & 0.6945 & 17.3126 \\
\hline BSS & 0.04 & 0.05 & 0.04 & 0.03 & 0.02 & 0.08 & 0.01 & 0.03 & 0.02 & 0.01 & 0.04 & 0.01 & 0.03 & 0.03 & 0.03 & 0.4615 & 17.7607 \\
\hline PMS & 0.05 & 0.05 & 0.06 & 0.03 & 0.07 & 0.02 & 0.04 & 0.01 & 0.02 & 0.01 & 0.01 & 0.01 & 0.03 & 0.03 & 0.11 & 0.5458 & 16.7313 \\
\hline RIB & 0.03 & 0.02 & 0.03 & 0.05 & 0.07 & 0.04 & 0.02 & 0.03 & 0.02 & 0.05 & 0.02 & 0.04 & 0.03 & 0.01 & 0.03 & 0.4855 & 18.1693 \\
\hline
\end{tabular}

Dari hasil perhitungan bobot konsistensi dapat dihitung perbandingan konsistensi sebagai berikut :

Hitung $\lambda$ maksimum $=$ Total Bobot Kriteria $/ 15$

$=258.314133118718 / 15$

$=17.2209422079145$

Hitung CR $\quad=\mathrm{CI} / \mathrm{CR}$

$=0.158635714285714 / 1,59$

$=0.0997708894878706$, karena CR $<0.1$ maka perbandingan konsisten $100 \%$.

Selanjutnya setelah menemukan bobot prioritas lokasi dengan cara mengulang yang sama seperti tabel kriteria sebelumnya dapat ditemukan lokasi yang dinyatakan layak berdasarkan perhitungan masing-masing kriteria dalam penilaian seperti pada "Tabel 6 Matriks Bobot Prioritas Berdasarkan Jarak Dengan Pasar Tradisional" dan "Tabel 7 Matriks Perbandingan Alternatif Berdasarkan Dampak Sosial Lingkungan". 
Tabel 6. Matriks Bobot Prioritas Berdasarkan Jarak Dengan Pasar Tradisional

\begin{tabular}{|c|c|c|c|c|c|c|c|}
\hline & SEN01 & SEN02 & SEN03 & SEN04 & SEN05 & SEN06 & SEN07 \\
\hline SEN01 & 1 & 1 & 5 & 1 & 1 & 5 & 1 \\
\hline SEN02 & 1.00 & 1 & 3 & 1 & 3 & 5 & 1 \\
\hline SEN03 & 0.20 & 0.33 & 1 & 3 & 5 & 3 & 3 \\
\hline SEN04 & 1.00 & 1.00 & 0.33 & 1 & 1 & 5 & 1 \\
\hline SEN05 & 1.00 & 0.33 & 0.20 & 1.00 & 1 & 5 & 1 \\
\hline SEN06 & 0.20 & 0.20 & 0.33 & 0.20 & 0.20 & 1 & 5 \\
\hline SEN07 & 1.00 & 1.00 & 1.00 & 1.00 & 1.00 & 0.20 & 1 \\
\hline Jumlah & 5.40 & 4.87 & 10.87 & 8.20 & 12.20 & 24.20 & 13.00 \\
\hline
\end{tabular}

Tabel 7. Matriks Perbandingan Alternatif Berdasarkan Dampak Sosial Lingkungan

\begin{tabular}{|l|c|c|c|c|c|c|c|c|c|}
\hline & SEN01 & SEN02 & SEN03 & SEN04 & SEN05 & SEN06 & SEN07 & $\begin{array}{c}\text { Jmlh } \\
\text { Brs }\end{array}$ & Bobot \\
\hline SEN01 & 0.1852 & 0.2055 & 0.4601 & 0.1220 & 0.0820 & 0.2066 & 0.0769 & 1.3382 & 0.1912 \\
\hline SEN02 & 0.1852 & 0.2055 & 0.2761 & 0.1220 & 0.2459 & 0.2066 & 0.0769 & 1.3181 & 0.1883 \\
\hline SEN03 & 0.0370 & 0.0685 & 0.0920 & 0.3659 & 0.4098 & 0.1240 & 0.2308 & 1.3280 & 0.1897 \\
\hline SEN04 & 0.1852 & 0.2055 & 0.0307 & 0.1220 & 0.0820 & 0.2066 & 0.0769 & 0.9088 & 0.1298 \\
\hline SEN05 & 0.1852 & 0.0685 & 0.0184 & 0.1220 & 0.0820 & 0.2066 & 0.0769 & 0.7595 & 0.1085 \\
\hline SEN06 & 0.0370 & 0.0411 & 0.0307 & 0.0244 & 0.0164 & 0.0413 & 0.3846 & 0.5755 & 0.0822 \\
\hline SEN07 & 0.1852 & 0.2055 & 0.0920 & 0.1220 & 0.0820 & 0.0083 & 0.0769 & 0.7718 & 0.1103 \\
\hline
\end{tabular}

Setelah semua kriteria lokasi dihitung, kemudian menghitung total bobot proiritas yang dilakukan dengan cara mengalikan bobot dari matrik perbandingan kriteria dengan bobot dari matrik perbandingan masing-masing kriteria lokasi seperti yang terlihat pada "Tabel 8 Hasil Perhitungan Matriks Bobot Prioritas dari Matriks Total Bobot Prioritas".

Tabel 8. Hasil Perhitungan Matriks Bobot Prioritas dari Matriks Total Bobot Prioritas

\begin{tabular}{|l|c|c|c|c|c|c|c|c|c|c|c|c|c|c|c|c|c|}
\hline & JPT & DSL & ROP & LKS & AKS & HNN & TRF & FSP & LSB & JLN & ARP & KPT & BSS & PMS & RIB & Total & $\%$ \\
\hline SEN01 & 0.0206 & 0.0422 & 0.0276 & 0.0348 & 0.0206 & 0.0259 & 0.0114 & 0.0110 & 0.0106 & 0.0019 & 0.0144 & 0.0072 & 0.0079 & 0.0090 & 0.0075 & 0.2527 & $26.47 \%$ \\
\hline SEN02 & 0.0203 & 0.0222 & 0.0243 & 0.0255 & 0.0092 & 0.0115 & 0.0114 & 0.0110 & 0.0082 & 0.0015 & 0.0080 & 0.0072 & 0.0035 & 0.0056 & 0.0048 & 0.1743 & $18.25 \%$ \\
\hline SEN03 & 0.0205 & 0.0282 & 0.0205 & 0.0064 & 0.0092 & 0.0115 & 0.0114 & 0.0098 & 0.0076 & 0.0014 & 0.0055 & 0.0072 & 0.0038 & 0.0053 & 0.0050 & 0.1533 & $16.06 \%$ \\
\hline SEN04 & 0.0140 & 0.0160 & 0.0106 & 0.0071 & 0.0092 & 0.0073 & 0.0130 & 0.0098 & 0.0049 & 0.0009 & 0.0044 & 0.0057 & 0.0042 & 0.0044 & 0.0022 & 0.1137 & $11.91 \%$ \\
\hline SEN05 & 0.0117 & 0.0167 & 0.0151 & 0.0066 & 0.0106 & 0.0073 & 0.0089 & 0.0059 & 0.0055 & 0.0010 & 0.0044 & 0.0057 & 0.0025 & 0.0027 & 0.0023 & 0.1069 & $11.20 \%$ \\
\hline SEN06 & 0.0089 & 0.0103 & 0.0066 & 0.0071 & 0.0069 & 0.0072 & 0.0089 & 0.0059 & 0.0022 & 0.0004 & 0.0024 & 0.0034 & 0.0020 & 0.0036 & 0.0027 & 0.0785 & $8.22 \%$ \\
\hline SEN07 & 0.0119 & 0.0106 & 0.0055 & 0.0071 & 0.0069 & 0.0052 & 0.0077 & 0.0059 & 0.0023 & 0.0004 & 0.0019 & 0.0036 & 0.0022 & 0.0020 & 0.0022 & 0.0753 & $7.89 \%$ \\
\hline
\end{tabular}

Berdasarkan total bobot prioritas yang diperoleh, maka dapat diambil keputusan bahwa lokasi yang layak untuk mendirikan gerai baru adalah Sen01, karena mempunyai total bobot prioritas tertinggi yaitu : 0,2527 atau 26,47\%. Pengujian aplikasi ini menggunakan metode pengujian black box. Berikut adalah hasil pengujian melihat dari hasil perhitungan manual, seperti terlihat pada "Tabel 9 Hasil Perhitungan Manual". 
Tabel 9. Hasil Perhitungan Manual

\begin{tabular}{|c|c|c|c|c|c|c|c|c|c|c|c|c|c|c|c|}
\hline \multirow{3}{*}{ No } & \multirow{3}{*}{ KRITERIA } & \multicolumn{14}{|c|}{ LOKASI } \\
\hline & & \multicolumn{2}{|l|}{ SEN01 } & \multicolumn{2}{|l|}{ SENO2 } & \multicolumn{2}{|l|}{ SEN03 } & \multicolumn{2}{|l|}{ SENO4 } & \multicolumn{2}{|l|}{ SENO5 } & \multicolumn{2}{|l|}{ SEN06 } & \multicolumn{2}{|l|}{ SEN07 } \\
\hline & & Data & Nitai & Data & Nilai & Data & Nilai & Data & Nilai & Data & Nilai & Dała & Nilai & Data & Nillai \\
\hline 1 & larak deran pasa tradsional & $150000 \mathrm{~m}$ & 3 &, $5000 \mathrm{~m}$ & 3 & $000-5000 m$ & 2 & $55000 \mathrm{~m}$ & 3 & $25001 \mathrm{~m}$ & 3 & $0.1001 \mathrm{~m}$ & 1 & $35000 \mathrm{~m}$ & 3 \\
\hline 2 & Dampak Sorial Lingknnge & S:ZS:DT:? & 3 & SS:9s27T & 2 & SS:689T:A5 & 1 & 5s:19s:307: & 2 & SS:19:14:15 & 2 & SS:25S:3T:12 & 3 & SS:29\$10T:1 & 3 \\
\hline 3 & Rencen Operai & $24 \mathrm{Jam}$ & 3 & $n 00000,00$ & 1 & 24 din & 3 & $0800-2100$ & 2 & 24 , the & 3 & 00000000 & 1 & $60.00-2100$ & 2 \\
\hline 4 & Lokat: & Sangu: Suategis & 3 & KurargStulegs & 2 & Strdegyis & 2 & Strategis & 2 & Srdegis & 2 & Strodeyjs & 2 & Strategs & 2 \\
\hline 5 & Aloes & Singz:Modah & 3 & Mustith & 2 & Mosth & 2 & Mudh & 2 & Singeradoth & 3 & Musth & 2 & Modat & 2 \\
\hline 6 & Huxian $($ arak $1.2 \mathrm{~km})$ & 35000 ortat & 3 & $5000-7500(2000 \mathrm{kk})$ & 2 & $5000-7360$ [2000) & 2 & 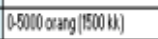 & 1 & 0.5600 [1500 kx] & 1 & $5000-350002000 \mathrm{kx}]$ & 2 & $0,5000(500 \mathrm{k})$ & 1 \\
\hline 7 & Trafik (dihitug 15 menit) & 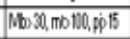 & 3 & Nob30, mb 100,pp & 3 & 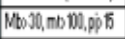 & 3 & 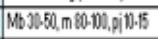 & 2 & Nob30,mb Do,pp & 3 & 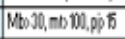 & 3 & Mas 30, mb 00, pi 5 & 3 \\
\hline 8 & Falitas Pendikng & Tetrinal & 3 & Rumah Sakt & 2 & R.mith Salt & 2 & Aunth Solitit & 2 & Teminis & 3 & Rumblatit & 2 & Aund Satit & 2 \\
\hline 9 & Lus Bangana & P, $20 \mathrm{~m}, \mathrm{~L}, 20 \mathrm{~m}$ & 3 & $P<10 \mathrm{~m} L<1$ 而 & 1 & $P(1) \mathrm{mL}<\mathrm{n} \mathrm{m}$ & 1 & P $>20 \mathrm{~m} L>20 \mathrm{~m}$ & 3 & P, $20 \mathrm{~m}, \mathrm{~L}, 20 \mathrm{~m}$ & 3 & $\mathrm{P} 1020 \mathrm{~m} \mathrm{~L} \mathrm{~L} 5.20 \mathrm{~m}$ & 2 & $P>20 \mathrm{~m} L>20 \mathrm{~m}$ & 3 \\
\hline 10 & Than & Fegrin & 3 & Kabupaten & 1 & Kabupaten & 1 & Proponsi & 2 & Negin & 3 & Negrio & 3 & Nagrar & 3 \\
\hline 11 & Asen Pactir & Setany & 2 & Kuratg & 1 & Kurang & 1 & Luas & 3 & Luas & 3 & Sedang & 2 & Sedong & 2 \\
\hline 12 & Eepenilikan Treah & Senóni & 3 & Sencíi & 3 & Sentri & 3 & Sevar 5 thetun & 2 & Sentín & 3 & Seva $>5$ thing & 2 & Sensiri & 3 \\
\hline 13 & Bear Sahnen & 5000. Wha & 3 & $300-500$ Jata & 2 & $301-500$ data & 2 & 55000.tata & 3 & $300-500$ data & 2 & $50-300.34 \mathrm{~A}$ & 2 & , 8000 Juta & 3 \\
\hline 14 & Kepemilikan Saham & Pibsá & 3 & Koperasi & 2 & Koperasi & 2 & Kelompol & 1 & Koperasi & 2 & Pibadi & 3 & Ketomyok & 1 \\
\hline 15 & Rakomendau Intzani yzan & Add & 3 & BeivanAds & 1 & Beiun $A$ da & 1 & Dilam Ploses & 2 & Dalin=Ploses & 2 & Aha & 3 & Dalim Ploses & 2 \\
\hline & Total Nilai & & 44 & & 28 & & 28 & & 32 & & 38 & & 33 & & 35 \\
\hline & Prosentase & & $18 \%$ & & $12 \%$ & & $12 \%$ & & $13 \%$ & & $16 \%$ & & $14 \%$ & & $15 \%$ \\
\hline
\end{tabular}

Dari pengujian yang telah dilakukan, dapat dirangkum seperti yang terlihat pada "Tabel 10 Rekapitulasi Hasil Perhitungan".

Tabel 10. Rekapitulasi Hasil Perhitungan

\begin{tabular}{|c|l|c|c|c|c|c|c|}
\hline Pengujian Ke & \multicolumn{1}{|c|}{ Lokasi } & Jumlah Lokasi & Jumlah Kriteria & Pengujian & Manual & Selisih & Lokasi Terpilih \\
\hline 1 & Sentolo & 7 & 15 & $26.47 \%$ & $18.49 \%$ & $7.98 \%$ & SEN01 \\
\hline 2 & Wates & 3 & 10 & $30.34 \%$ & $30.00 \%$ & $0.34 \%$ & WAT02 \\
\hline 3 & Pengasih & 5 & 5 & $32.40 \%$ & $29.41 \%$ & $2.99 \%$ & PEN04 \\
\hline 4 & Nanggulan & 10 & 10 & $19.89 \%$ & $16.76 \%$ & $3.13 \%$ & NAN02 \\
\hline 5 & Temon & 15 & 7 & $11.22 \%$ & $16.28 \%$ & $-5.06 \%$ & TEM07 \\
\hline 6 & Kalibawang & 3 & 3 & $42.01 \%$ & $40.91 \%$ & $1.10 \%$ & KAL01 \\
\hline 7 & Samigaluh & 6 & 8 & $20.80 \%$ & $22.45 \%$ & $-1.65 \%$ & SAM02 \\
\hline 8 & Panjatan & 9 & 9 & $14.44 \%$ & $15.34 \%$ & $-0.90 \%$ & PAN01 \\
\hline
\end{tabular}

Berdasarkan hasil pengujian dengan kasus uji sample, dengan berbagai jumlah calon lokasi maupun berbagai jumlah kriteria terlihat bahwa hasil pengujian kasus uji sample dan perhitungan secara manual memiliki hasil yang sama dalam pemilihan lokasi terpilih.

Hasil dari 8 kali pengujian dengan jumlah kriteria dan lokasi yang berbeda, 3 pengujian manual diperoleh hasil prosentase yang lebih besar. Sehingga tingkat sensitifitas sistem dapat dihitung dengan persamaan sebagai berikut :

$$
\text { Sencitivity }=8 /(8+3) \times 100 \%=72.72 \%
$$

Hasil perhitungan sensitifitas menujukan nilai sebesar $72.72 \%$. Berdasarkan hasil pengujian kasus diatas maka dapat disimpulkan bahwa sistem pendukung keputusan ini sudah dapat berfungsi dengan baik untuk melakukan pemilihan lokasi pendirian gerai baru.

\section{KESIMPULAN}

Berdasarkan tahapan penelitian yang telah dilakukan dapat disimpulkan bahwa, dalam pengembangan sebuah sistem pendukung keputusan diperlukan berbagai data kriteria untuk menentukan kelayakan sebuah lokasi pendirian minimarket. Semakin lengkap data yang diperoleh, maka sistem akan memberikan penilaian semakin baik dari sisi akurasi. Sistem Pendukung Keputusan Untuk Menentukan Lokasi Pendirian Gerai Baru pada Minimarket 
Alfamart dengan memanfaatkan model Fuzzy Analytical Hierarchy Process (F-AHP) hanya merupakan salah satu alat bantu dalam pengambilan keputusan untuk menentukan lokasi mendirikan gerai baru oleh divisi pengembangan.

\section{UCAPAN TERIMA KASIH}

Peneliti mengucapkan terima kasih kepada Direktorat Riset dan Pengabdian Masyarakat (DRPM), Kementerian Riset, Teknologi, dan Pendidikan Tinggi atas dukungan biaya penelitian yang diberikan dan semua pihak yang telah membantu terselesaikannya penelitian ini.

\section{DAFTAR PUSTAKA}

\section{Rujukan Buku:}

Morreale, P. A., \& Anderson, J. A. (2015). Software Defined Networking Design and Development. Florida: CRC Press .

Puspitasari, D. N., \& Subowo, A. (2014). Implementasi Peraturan Daerah Kota Semarang Nomor 1 Tahun 2014 Tentang Penataan Toko Modern (Kajian Pendirian Minimarket di Kecamatan Banyumanik Kota Semarang).

\section{Rujukan Jurnal:}

Faisol, A., Muslim, M. A., \& Suyono, H. (2014). Komparasi Fuzzy AHP dengan AHP pada Sistem Pendukung Keputusan Investasi Properti. Jurnal EECCIS, 8(2), 123-128.

Fuadi, R. I., \& Juniani, A. I. (2015). Faulty Behaviour Risk Melalui Pendekatan Metode. Jurnal Teknik Industri, X(2), 85-96.

Septilia Arfida. (2012). Implementasi Fuzzy Terhadap Sistem Pendukung Keputusan Dalam Menentukan Kelayakan Pembuayaan Pengajuan Kredit Barang. Jurnal Informatika, $12(2), 146-155$.

Sonalitha, E., Sarosa, M., \& Naba, A. (2015). Pemilihan Pemasok Bahan Mentah pada Restoran Menggunakan Metode Fuzzy Analytical Hierarchy Process. Jurnal EECCIS, 9(1), 49-54.

\section{Rujukan Prosiding:}

Saraswati. (2008). Analisis Dampak Keberadaan Minimarket Indomaret dan Alfamart Terhadap UKM Dalam Kaitannya Dengan Peraturan Presiden Nomor 112 Tahun 2007 Tentang Penataan dan Pembinaan Pasar Tradisional, Pusat Perbelanjaan dan Toko Modern.

Wahyuni, S., \& Sri, H. (2012). Sistem Pendukung Keputusan Model Fuzzy AHP Dalam Pemilihan Kualitas Perdagangan Batu Mulia ,. Ijccs, 6(1), 43-54. https://doi.org/10.22146/ijccs.2140 